\title{
Articular scanning and external counting in experimental synovitis in the guinea-pig
}

\author{
A. G. MOWAT,* T. F. DISNEY, $\dagger$ AND J. H. VAUGHAN $\dagger$ \\ From the Department of Medicine, University of Rochester School of Medicine and Dentistry, Rochester, \\ New York, U.S.A.
}

It is often difficult to make an accurate assessment of the intensity of synovitis and arthritis in small animals. In preparation for a study of experimentally-induced synovitis in guinea-pigs, articular scanning and external counting techniques were evaluated.

\section{Material and methods}

Acute synovitis was induced in one elbow joint of 300 to $400 \mathrm{~g}$. guinea-pigs by the intra-articular injection of the polyene antibiotic Nystatin $(10,000$ i.u. in $0.1 \mathrm{ml}$. physiological saline) (Weissmann, Pras, and Rosenberg, 1967). At 24-hr intervals for up to 7 days the intensity of the synovitis was evaluated clinically and by scanning and external counting techniques and compared with the non-injected elbow. Control studies were performed to ensure that the two elbow joints in untreated animals were similar and that the intra-articular injection of the same volume of physiological saline $(0.1 \mathrm{ml}$.) did not alter the scanning or external counting characteristics of the joint. Radiographs taken after the injection of radio-opaque dye into nine elbow joints confirmed the reliability of the intra-articular injection technique. It was not found necessary to shave the area around the elbow joints.

The guinea-pigs were anaesthetized by the intraperitoneal injection of sodium pentobarbitone and fixed to a board in a standard geometric pattern using rubber bands. Articular scanning and external counting studies were conducted with a Picker Magna-scanner with a


of radioiodinated ( $\left.{ }^{131}\right)$ human serum albumin (RISA) in a dose of 10 to $20 \mu \mathrm{c}$. $/ \mathrm{kg}$. The pulse height analyser was set to accommodate the $364 \mathrm{Kv}$ peak of the $\mathrm{I}^{131}$ spectrum. Shielding of the trunk of the animal was not found to be necessary. Scintillographic studies were unsatisfactory as the small areas involved allowed insufficient definition.

Although RISA is fully mixed in the peripheral blood within 10 to 15 minutes of the intravenous injection, the RISA was injected $24 \mathrm{hrs}$ before the first scanning and external counting assessment to allow it to reach equilibrium with the interstitial and synovial fluids. It was found that a single injection of RISA ( $20 \mu \mathrm{c} . / \mathrm{kg}$.) provided adequate residual radioactivity for scanning and external counting procedures to be carried out for up to 7 days.

An attempt was made to determine the percentage of radioactivity in the area of the joint contributed by RISA circulating in the hypervascular tissue compared to the percentage contributed by RISA in the interstitial and synovial fluids. Synovitis was induced and RISA $(10 \mu \mathrm{c}$.) injected in three animals on Day 0 and the synovitis was assessed by external counting on Day 4 . Then a further injection of RISA $(10 \mu \mathrm{c}$.) was given intravenously and a re-assessment of the synovitis made after an interval of 20 minutes. In an additional three animals, RISA $(10 \mu \mathrm{c}$.) was injected on Day 0, and synovitis was induced on Day 3 and assessed on Day 4 before and after a second injection of RISA $(10 \mu \mathrm{c}$.).

\section{Results}

These are expressed as the ratio of the radioactivity of the injected joint to the non-injected joint $\times 100$, after subtraction of the background activity. Thus a value of 100 represents no detectable inflammation. The radioactivity was calculated either by absolute counts per minute from the joints with the machine centred over a standard point (tip of the elbow), or by counting the number of marks on the rectilinear scan in a standard area around the joint. Control studies showed no difference between the elbow joints in untreated animals, and the intra-articular injection of physiological saline to one elbow joint did not alter its external counting or scanning characteristics compared with the non-injected joint.

Individual results for the ratio of radioactivity between the injected and non-injected joints for counts per minute and the rectilinear scan in eleven animals are set out in Table I (overleaf). The scanner was repositioned after each reading. It can be seen that the two methods are reproducible and that the 
Table I Assessment of joint inflammation by external counting and rectilinear scan

Radioactivity injected joint

$\frac{\text { Radioactivity non-injected joint }}{100}$

\begin{tabular}{|c|c|c|c|c|c|c|}
\hline \multirow[t]{2}{*}{ Animal } & \multicolumn{3}{|l|}{ Counts per minute } & \multicolumn{3}{|l|}{ Rectilinear scan } \\
\hline & Values & Mean value & Percentage error & Values & Mean value & Percentage error \\
\hline 1 & & & & $212,200,200$ & 204 & $2 \cdot 6$ \\
\hline 2 & $178,173,173,169$ & 173 & $1 \cdot 3$ & & & \\
\hline 3 & $\begin{array}{l}164,164,161,161, \\
161,160,159,151, \\
148\end{array}$ & 158 & $2 \cdot 9$ & & & \\
\hline 4 & & & & $235,226,221,211$ & 223 & $3 \cdot 2$ \\
\hline 5 & $295,280,280,268$ & 281 & $2 \cdot 6$ & & & \\
\hline 6 & $114,112,112,106$ & 111 & $2 \cdot 3$ & $118,114,111,105$ & 112 & $3 \cdot 6$ \\
\hline 7 & $155,153,153,147$ & 152 & $1 \cdot 6$ & $156,155,149,142$ & 150 & $3 \cdot 0$ \\
\hline 8 & $150,144,144,142$ & 145 & $1 \cdot 7$ & $156,145,143,135$ & 145 & $4 \cdot 0$ \\
\hline 9 & $147,139,138,138$ & 140 & $2 \cdot 1$ & $135,131,130,127$ & 131 & $1 \cdot 7$ \\
\hline 10 & $215,207,202,196$ & 205 & $2 \cdot 9$ & $227,204,198,191$ & 205 & $5 \cdot 5$ \\
\hline 11 & $106,105,105,102$ & 104 & $1 \cdot 4$ & $104,102,102,100$ & 102 & $1 \cdot 0$ \\
\hline
\end{tabular}

correlation between the method is good. The mean percentage error for the external counting method was $2 \cdot 1$ per cent. and for the rectilinear scan method $3 \cdot 1$ per cent.

'Clinical' activity of the synovitis was graded as $0,+,++,+++$, or ++++ , on the basis of swelling, warmth, and tenderness. This subjective clinical grading was undertaken before radioactive assessment in each of 105 cases and the results are compared in the Figure. Also in the Figure an attempt has been made to correlate an objective system of grading with the radioactive assessment. Based upon the accuracy of the method described above, all ratios of radioactivity of $100 \pm 5$ have been given an objective grading of 0 . All ratios of radioactivity above 230 have been graded as ++++ ; and the remaining intervals have been divided equally as grades,+++ , and +++ . It is clear that neither subjective nor objective grading represents the information as well as the absolute values.

In Table II (opposite) the results of the external counting of synovitis which had been present for 1 or 4 days, using the radioactivity from RISA which had been injected 4 days or 20 minutes previously, are presented. The ratio resulting from the use of RISA which had been injected only 20 minutes previously produced mean values 8.7 per cent. lower than those resulting from the use of RISA which had been injected 4 days previously. This probably represents

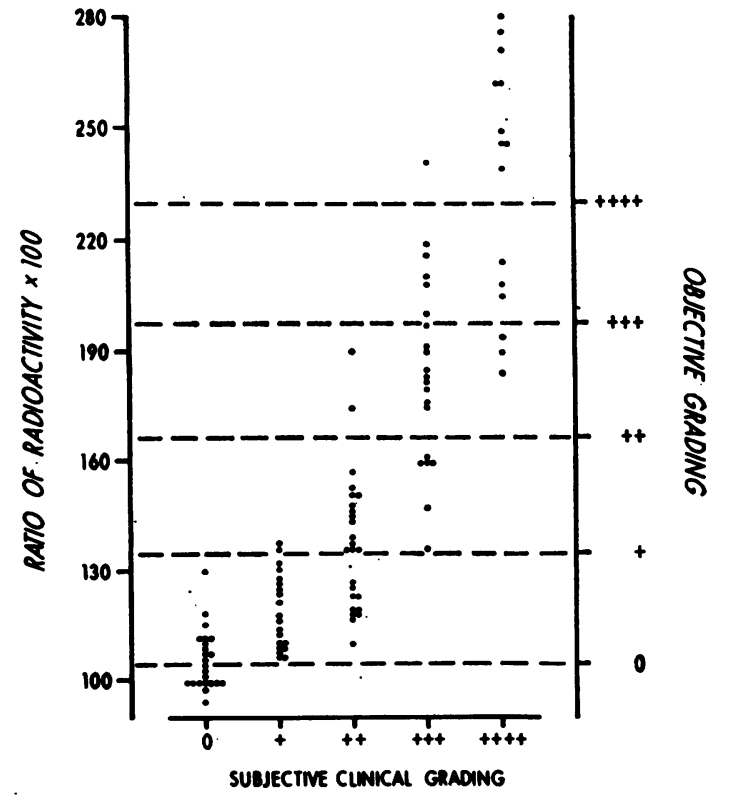

FIGURE Comparison of 'clinical' grading and radioactive assessment in experimental arthritis.

failure of the RISA to reach equilibrium in the interstitial and synovial fluids within the $\mathbf{2 0}$ minute period of time. 
Table II Assessment of synovitis using two injections of RISA

\begin{tabular}{|c|c|c|c|c|c|}
\hline \multirow{2}{*}{$\begin{array}{l}\text { Order of } \\
\text { injections }\end{array}$} & \multirow[t]{2}{*}{ Day } & \multirow[t]{2}{*}{ Animal } & \multicolumn{3}{|l|}{ Ratio of radioactivity } \\
\hline & & & $\begin{array}{l}4 \text { days after first RISA } \\
\text { injection }\end{array}$ & $\begin{array}{l}20 \text { minutes after second RISA } \\
\text { injection }\end{array}$ & Percentage difference \\
\hline $\begin{array}{l}\text { RISA } \\
\text { Nystatin } \\
\text { RISA }\end{array}$ & $\begin{array}{l}0 \\
3 \\
4\end{array}$ & $\begin{array}{l}1 \\
2 \\
3\end{array}$ & $\begin{array}{l}240 \\
256 \\
232\end{array}$ & $\begin{array}{l}225 \\
220 \\
212\end{array}$ & $\begin{array}{r}6 \cdot 3 \\
-14 \cdot 0 \\
-8 \cdot 6\end{array}$ \\
\hline $\begin{array}{l}\text { RISA } \\
\text { Nystatin } \\
\text { RISA }\end{array}$ & $\begin{array}{l}0 \\
0 \\
4\end{array}$ & $\begin{array}{l}4 \\
5 \\
6\end{array}$ & $\begin{array}{l}175 \\
152 \\
140\end{array}$ & $\begin{array}{l}165 \\
140 \\
126\end{array}$ & $\begin{array}{r}5.4 \\
-7.9 \\
-10.0\end{array}$ \\
\hline
\end{tabular}

\section{Discussion}

Various methods and isotopes have been used to assess inflammation in human joint studies. Dick, St Onge, Whaley, Gillespie, Boyle, Jasani, and Buchanan (1969) and Dick, Whaley, St Onge, Downie, Boyle, Nuki, Gillespie, and Buchanan (1970) used intra-articular injections of radioXenon to measure blood flow in synovial tissue. Weiss, Maxfield, Murison, and Hidalgo $(1965,1966)$ used intravenous injections of RISA and scanning techniques to measure the vascularity in the joints of patients with rheumatoid arthritis and normal subjects. They found a good correlation with their clinical assessment of the activity of the joint disease. Whaley, Pack, Boyle, Dick, Downie, Buchanan, and Gillespie (1968), Green and Hays (1969), and McCarty, Polcyn, and Collins (1970a) applied scanning and scintiphotographic techniques over normal and diseased joints after intravenous injections of radio-technetium $\left(\mathrm{M}^{99} \mathrm{TcO}_{4}\right)$. All these methods measure primarily the vascularity of the synovial tissue, although the radioactivity may be increased slightly by accumulation of the tagged material in joint effusions (Weiss and others, 1965; McCarty, Polcyn, Collins, and Gottschalk, 1970b) and by synovial tissue binding in the case of radiotechnetium (Green and Hays, 1969; McCarty and others, 1970b). Our results support these findings. Probably the best application of these methods is in serial studies to follow medical or surgical therapeutic measures, rather than as a diagnostic aid (McCarty and others, 1970a). This is the application used by ourselves (Mowat, Disney, and Vaughan, 1970).

These methods have only rarely been applied to animal studies. Sholkoff, Glickman, Schachter, and Rowland (1969) used intravenous injections of radio-technetium and external counting and scanning methods over rabbit knee joints in a study of Bedsoniae-induced arthritis. There are no reports of similar techniques being used on animals as small as our guinea-pigs.

For patient studies radio-technetium has certain technical advantages (Lancet, 1968), but for animal studies, where considerations of radiation are less important, RISA is entirely satisfactory. The isotope is readily available without the need for the molybdenum column technique required for the production of technetium. The half-life of RISA is approximately $40 \mathrm{hrs}$ in the guinea-pig compared with $6 \mathrm{hrs}$ for technetium and this may be important when studies on several consecutive days are planned and repeated intravenous injections are difficult. In human studies with RISA it is advisable to administer iodine before and after the injections to prevent accumulation of the isotope in the thyroid gland. This was felt to be unnecessary in our animals. By using the ratio of radioactivity between injected and non-injected joints, the vascularity of the joints can be quantified without consideration of the animal's weight or the dose of isotope injected or remaining in the animal.

\section{Summary}

A simple, reproducible method of assessment of synovitis and arthritis in small guinea-pigs is described. The changes in joint vascularity induced by the intra-articular injection of Nystatin were measured by scanning and external counting techniques after the intravenous injection of radioactive $\left(\mathrm{I}^{131}\right)$ human serum albumin. It is suggested that this method may have wider application in the study of experimental arthritis in animals.

We wish to thank Prof. P. Rubin, Radiotherapy Department, University of Rochester, New York, U.S.A., for the supplies of radioactive $\left(\mathrm{I}^{131}\right)$ human serum album in and for the use of the Picker Magna-scanner.

This work was supported by U.S.P.H.S. grants $A M-02443$ and $A 1-28$.

During the period of this study A.G.M. was in receipt of a travel grant from the Arthritis and Rheumatism Council, T.F.D. was in receipt of a fellowship and training grant from the Medical Research Council of Canada, and J.H.V. was the recipient of a Research Career Award from the National Institutes of Health. 


\section{References}

Dick, W. C., St Onge, R. A., Whaley, K., Gillespie, F., Boyle, J. A., Jasani, M. K., and Buchanan, W. W. (1969) Ann. rheum. Dis., 28, 197 (Measurement of synovial blood flow in normal and diseased joints).

—, Whaley, K., St ONGe, R. A., Downie, W. W., Boyle, J. A., Nuki, G., Gillespie, F. C., AND BuChanan, W. W. (1970) Clin. Sci., 38, 123 (Clinical studies on inflammation in human knee joints: Xenon $\left({ }^{133} \mathrm{Xe}\right)$ clearances correlated with clinical assessment in various arthritides and studies on the effect of intra-articularly administered hydrocortisone in rheumatoid arthritis).

Green, F. A., AND HaYs, M. T. (1969) Arthr. and Rheum., 12, 299 (Joint scanning: mechanism and application).

Lancet (1968) Editorial, 1, 131 (99 ${ }^{m}$ Tc: a versatile isotope).

MCCarty, D. J., Polcyn, R. E., ANd Collins, P. A. (1970a) Arthr. and Rheum., 13, 21 (99m Technetium scintiphotography in arthritis, 2. Its nonspecificity and clinical and roentgenographic correlations in rheumatoid arthritis).

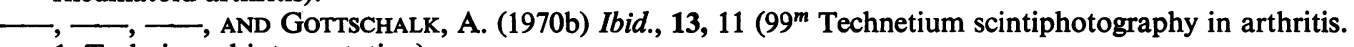
1. Technic and interpretation).

Mowat, A. G., Disney, T. F., And Vaughan, J. H. (1971) Ann. rheum. Dis., 30, 187 (The effect of iron dextran, gold thiosulphate, and hydrocortisone acetate on experimental synovitis in the guinea-pig).

Sholkoff, S. D., Glickman, M. G., SchaChTER, J., AND Rowland, M. (1969) Arthr. and Rheum., 12, 220 (External counting and scintiphotography in rabbits with arthritis).

Weiss, T. E., MaXfield, W. S., Murison, P. J., and Hidalgo, J. U. (1965) Ibid., 8, 976 (Iodinated human serum albumin $\left(\mathbf{I}^{131}\right)$ localization studies of rheumatoid arthritis joints by scintillation scanning).

,,,$----(1966)$ Sth. med. J., 59, 484 (Scintillation scanning in rheumatoid arthritis).

Weissmann, G., Pras, M., AND Rosenberg, L. (1967) Arthr. and Rheum., 10, 325 (Arthritis induced by Filipin in rabbits).

Whaley, K., Pack, A. I., Boyle, J. A., Dick, W. C., Downie, W. W., Buchanan, W. W., ANd Gillespie, F. C. (1968) Clin. Sci., 35, 547 (The articular scan in patients with rheumatoid arthritis; a possible method of quantitating joint inflammation using radio-technetium). 